\title{
Protocadherin Fat 3
}

National Cancer Institute

\section{Source}

National Cancer Institute. Protocadherin Fat 3. NCI Thesaurus. Code C143135.

Protocadherin Fat 3 (4589 aa, $506 \mathrm{kDa}$ ) is encoded by the human FAT 3 gene. This protein is involved in cell-cell adhesion. 